مرتقبات العمل الإرشادى الزراعى مع الريفيات الحاصلات على قروض من بنك التنمية والإنتمان الزراعى لتنفيذ مشروع تربية إناث الماشية وغير المقترضات في بعض قرى محافظة البحيرة

$$
\text { أمل عبد الرسول أحمد فايد' - مايد }
$$

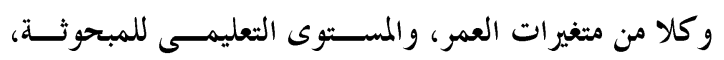

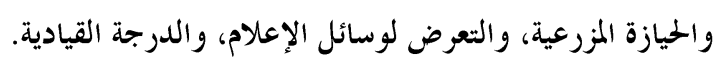

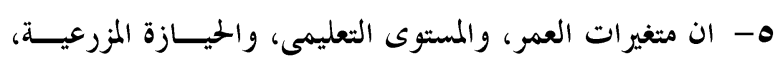

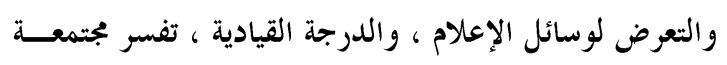

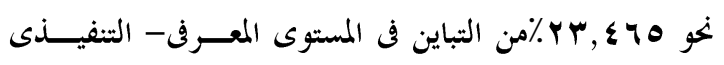

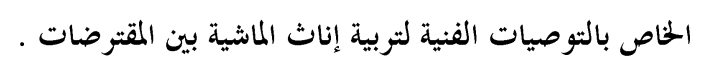

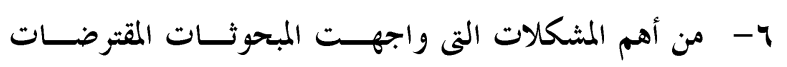

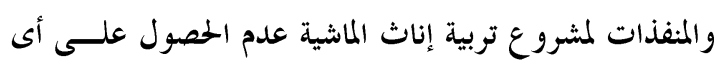
دورات تدريبية في هذا الججال، وإرتفاع أسعار الأعلاف وعدم إندات توافرها.

\section{المقدمـــة والمشكلة البحثية}

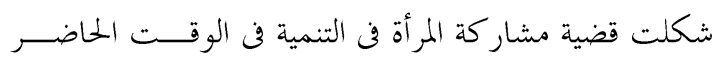

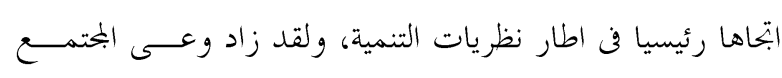

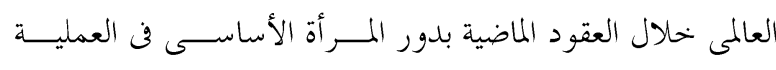

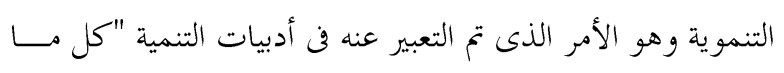

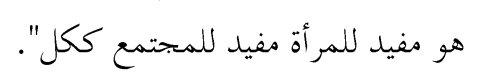

إن إبحاه العالم حاليا الم تبنى النظام الإقتصادى العالمى الجديد

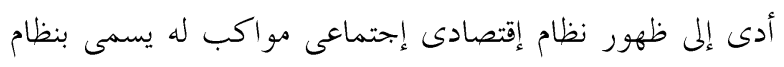

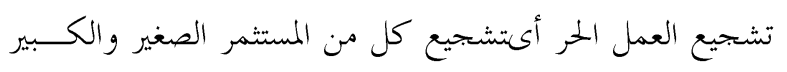

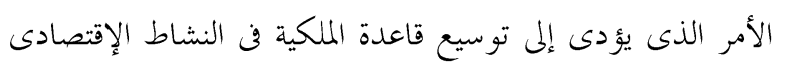

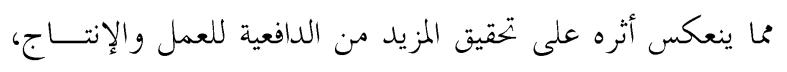

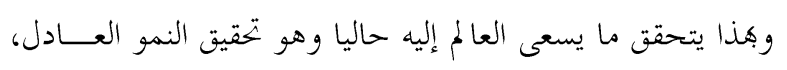

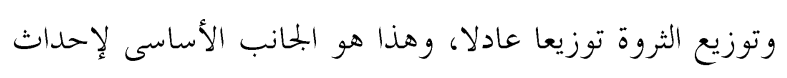

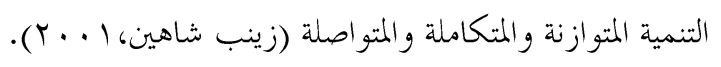

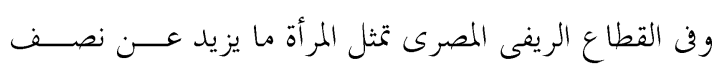

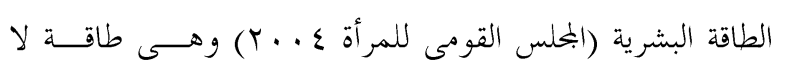

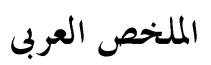

استهدف البحث بصفة أساسية دراسة مقارنة لمرتقبات العمـل

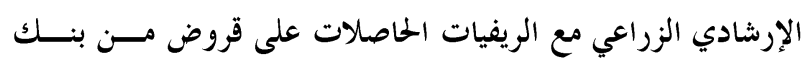

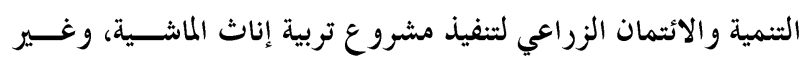

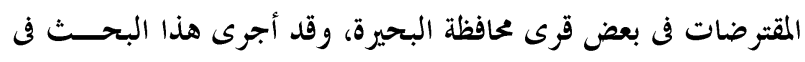

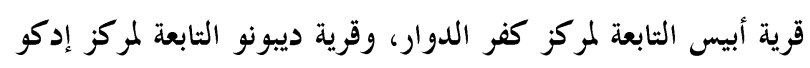

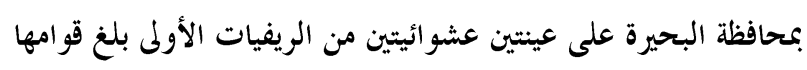

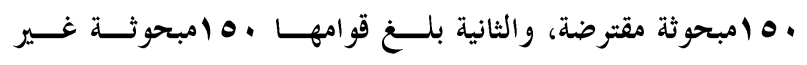
مقترضة، وقد تم جمع البيانات عن طريق إستمارة إســبيان بالمقابلــة إنسة

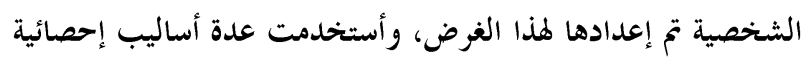

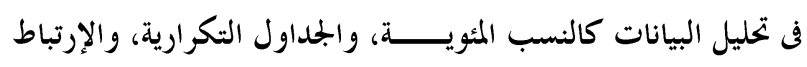

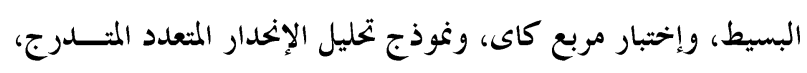

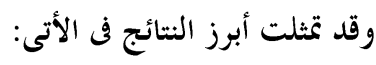
1- أن • V\% من المبحوثات الحائزات لمثروع تربية إنــاث الماشـــية

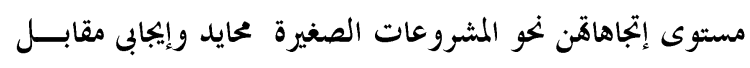

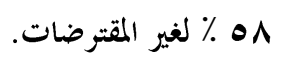

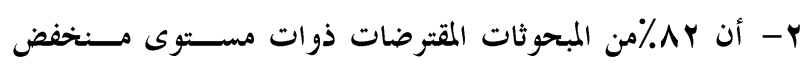

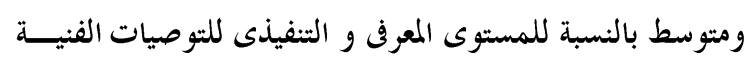
لتربية إناث الماشية.

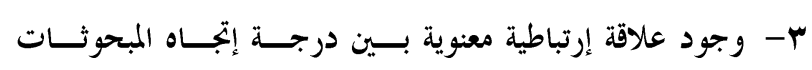

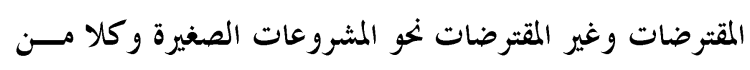

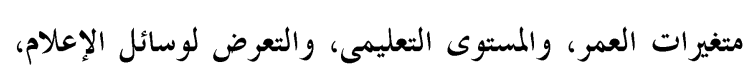

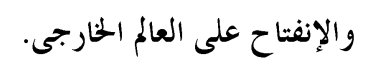

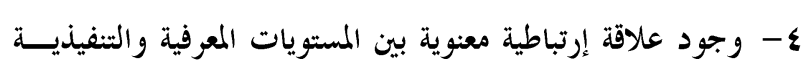

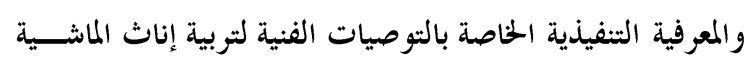


هذا الإهتمام يستند الم عدة حقائق لعل أهمها ( (1) إتفاق غالبيــة

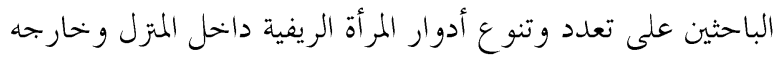

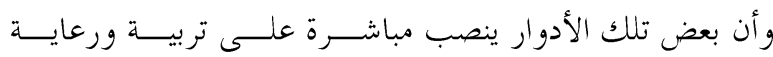

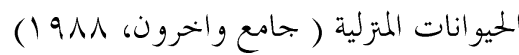

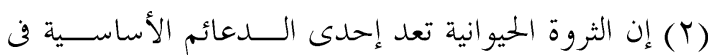

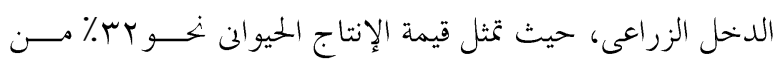

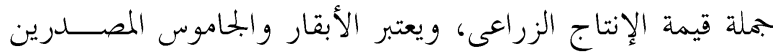

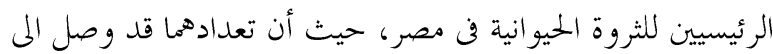

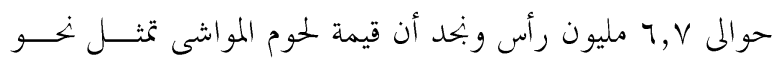

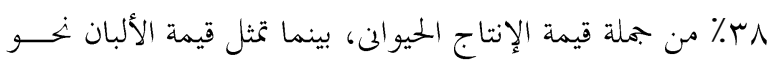

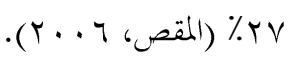

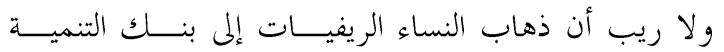
و الإئتمان الزراعى للحصول على قروض لإقامة مشروعات يـثير

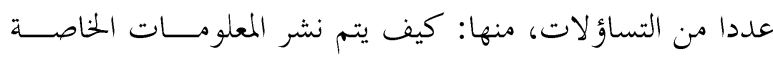

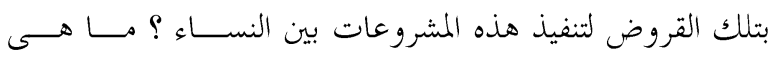

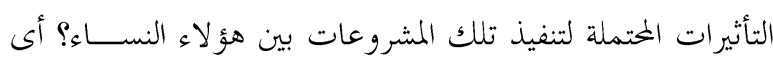

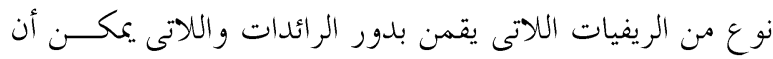

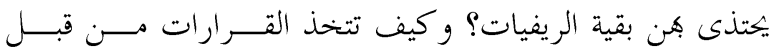

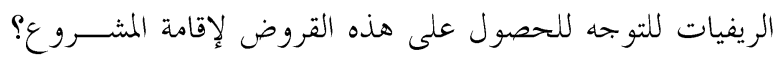
وما هو الدور المرتقب للإرشاد الزراعى لمساعدة هؤلاء الريفيات

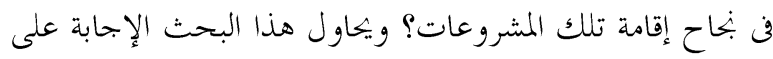

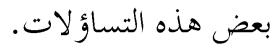

\section{أهداف البحث}

يستهدف هذا البحث بصفة رئيسية دراسة مرتقبات العمــل الإرشادى الزراعى مع الريفيات الحاصلات على قروض من بنك

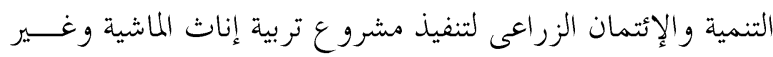

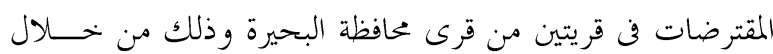
تحقيق بحموعة من الأهداف الفرعية هى: 1- التعرف على بعض الخصائص الإجتماعيــة- الإقتصــادية

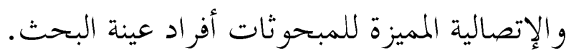
r- التعرف على إبتاه المبحوثات نغو المشروعات الصغيرة سواء المقترضات وغير المقترضات.
يستهان بها ولا يمكن إغفالها في مختلف جوانب الحياة الريفيسـة. وفي

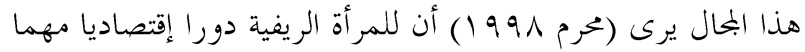
يجعل منها أكبر القوى المؤثرة في التنمية سواء بترشيد الإستهلاك أو

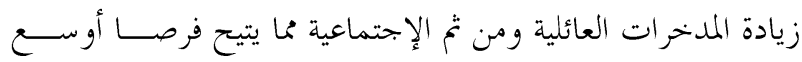
للإستثمار وخلق الطاقات الإنتاجية الجلديدة في المجتمع.

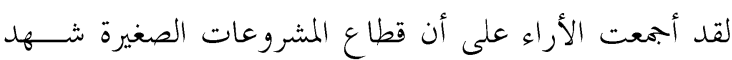
زيادة كبيرة في نسبة العمالة خلال العقدين الماضيين خاصة في ظـلـل

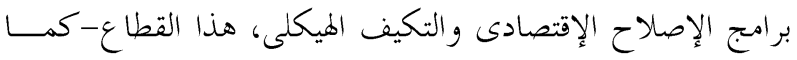

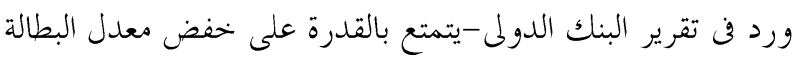

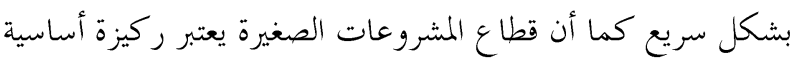

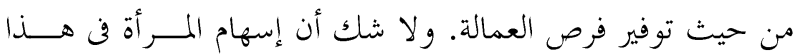

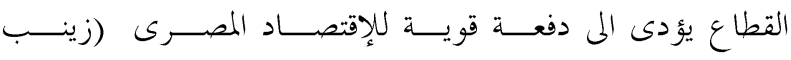

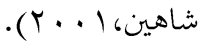

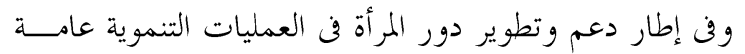

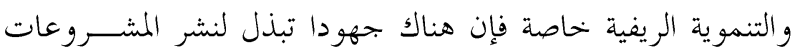

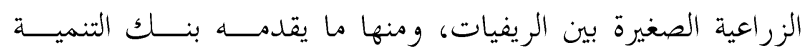

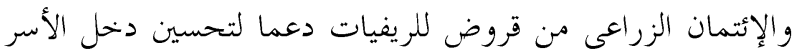

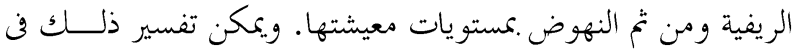
ضوء عدة مرتكزات لعل أهمها يتمثل فن: (1) الحاجة الملحة إلى تكثيف الجهود لمقابلة الزيادة المضطردة

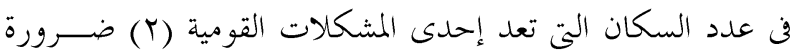
تصدى الجهود التنموية الريفية لظاهرة الفقر في مصر حيث تصـل

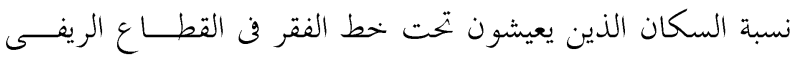

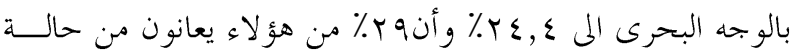
الفقر المدقع وأن أحد أسباب هذه الظاهرة يعزى المى حرمان المــــأة

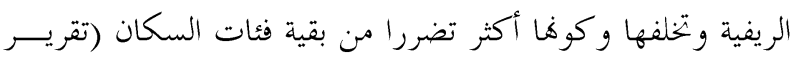

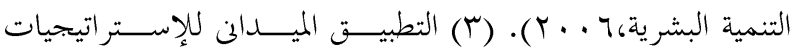

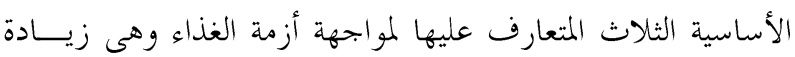
الإنتاج، وتخفيض الفاقد في عمليات ما بعد الخصاد ، ودعم المــــأة الريفية (1981, Danber ) وإتساقا مع ما تقدم فقد حظيت قروض تربية إنـاثـاث الماشــية

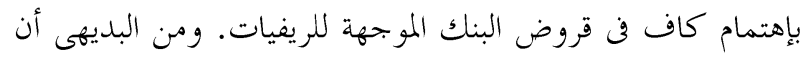


لأدوار الآخرين الذين يتبادل معهم أداء الأدوار. فالأدوار والمراكز مفاهيم تمكننا من إدراك السلوك الاجتماعي في الموقف ليتسنئ لنا

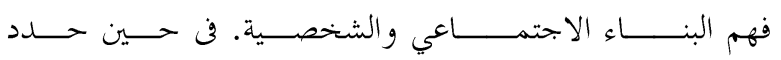
(Gibson,1979)

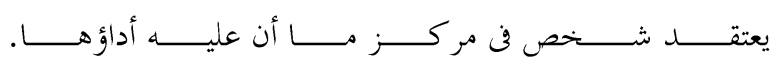

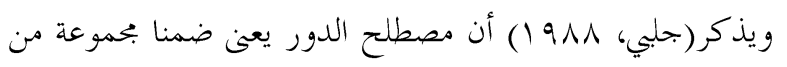

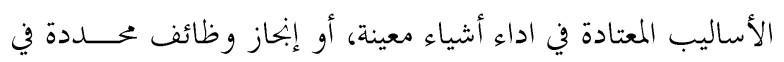

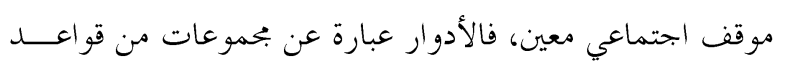

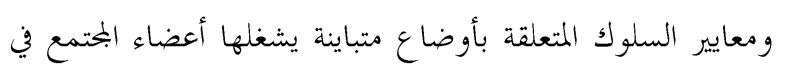
علاقتهم بعضهم بالأخر وفن علاقتهم بالمحتمع ككل.

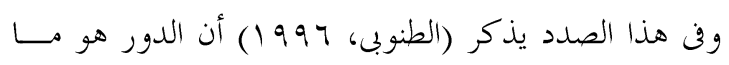

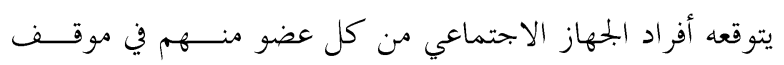

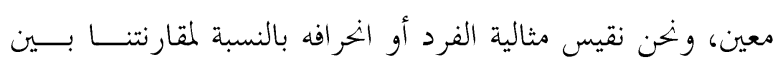

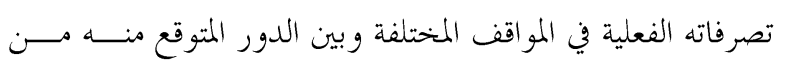

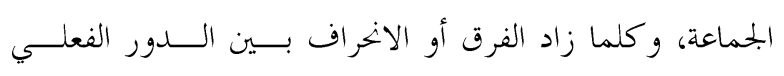

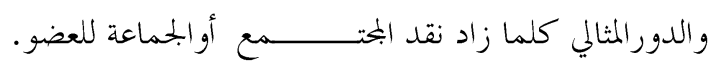
وينظر اخرون للدور على أنه بمموعة من أنمــاط سـلو كية

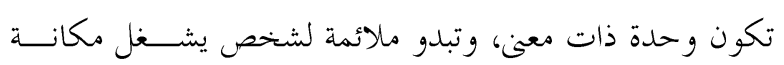

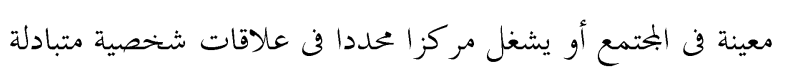

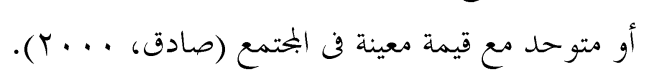
مفهوم المشروع الإنتاجى الزراعى الصغير:

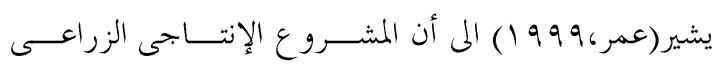

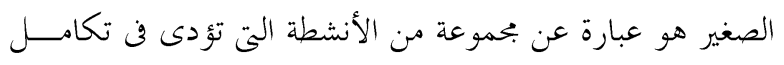

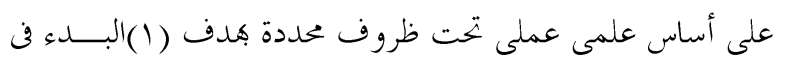

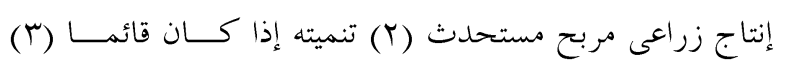

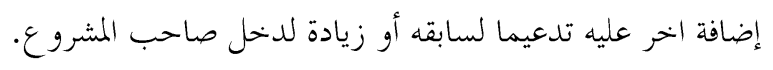
ويرى (أبوحطب، 999 1) أن المشروع الصــير إســثمار

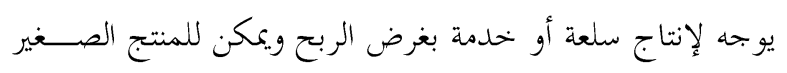

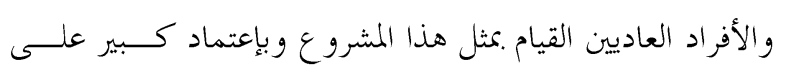
تمويلهم الذاتىهوإمكانياهم المادية، كما يتميز بأن درجة المخــــاطرة فيه ليست عالية وله درجة عالية للمواءمة مع البيئة. r- التعرف على المستوى المعرف و التنفيذى الخاص بالتوصـيات

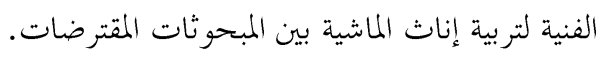
ع - التعرف على العلاقات الإرتباطية بين درجات إبتحاه المبحوثات

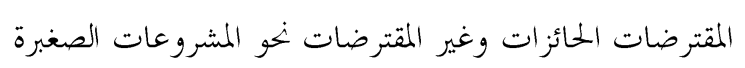

$$
\text { و بعض الخصائص المميزة لهن. }
$$

ه- دراسة العلاقات الإرتباطية بين الخصائص المميزة للمبحوثات

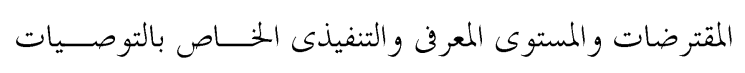

$$
\text { الفنية لتربية إناث الماشية. }
$$

7 - التعرف على أهم المشكلات التي و اجهت الريفيات المبحوثات

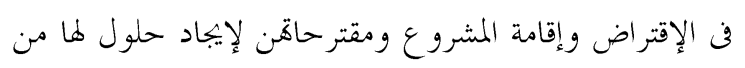

$$
\text { وجهة نظرهن. }
$$

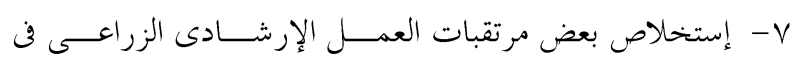

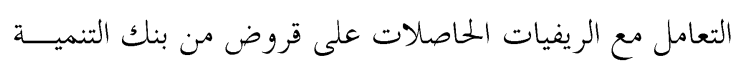

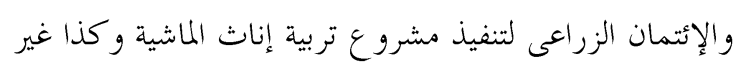

$$
\text { المقتر ضات. }
$$

\section{الإستعر اض المرجعى}

أولا: الإطار النظرى:

تعتبر قضية التنمية إحدى التحديات التى تواجه الدول الناميــة،

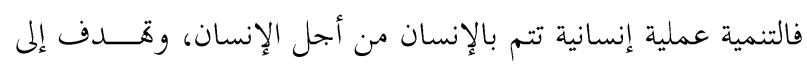

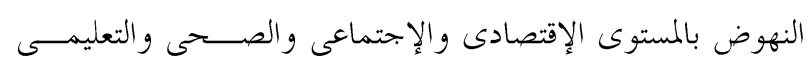

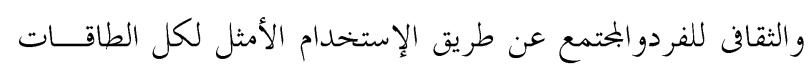

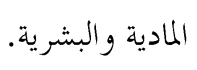

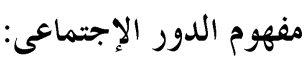

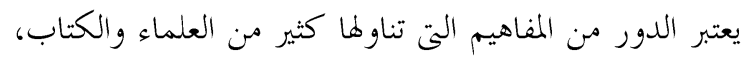

وتتعدد مفاهيم الدور تبعا لوجهات نظر من يتناولونه بالتعريف. فيذكر (فرج،91911) أن البناء الإجتماعى يتكون من بحموعة

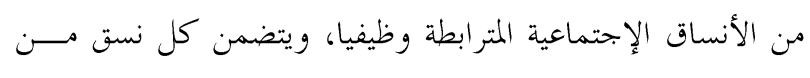
بحموعة من الأشخاص تربطهم علاقات إجتماعية، ويشغلون مراكز

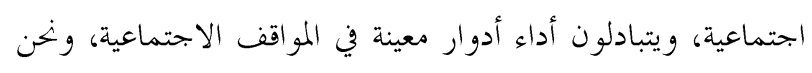

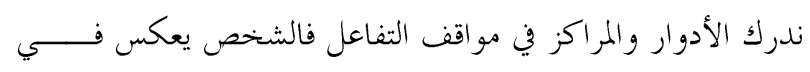

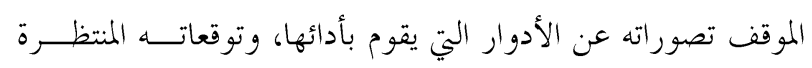


نتائجها وجود علاقة إرتباطية معنوية بين درجة نجاح المرأة الريفية

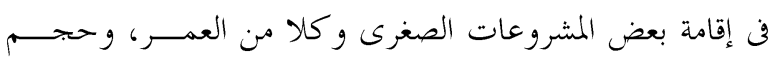

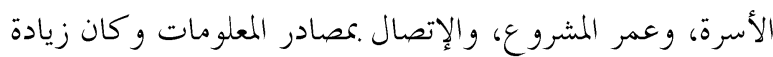

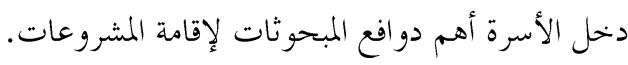
دراسة (عبد الوهاب، V . . Y)عن"دور المرشدين الــزراعيين في تنمية الخريجين من الشباب الريفى في بجال المشروعات الزراعيــة

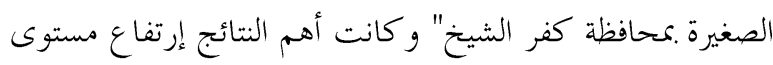

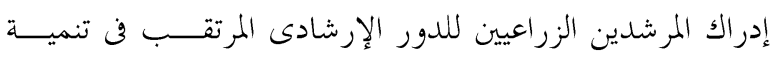

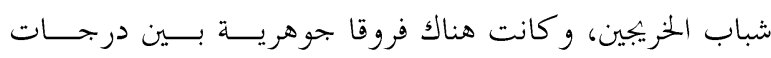
الإدراك والتوقع للدور الإرشادى الزراعى المرتقب.

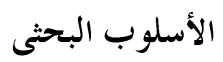

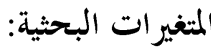

\section{أ- المتغيرات المستقلة وطرق قياسها:}

1- السن: يقصد به عمر المبحوثة لأقرب سنة ميلاديسـة وقــت

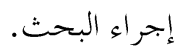

ץ- الحالة التعليمية للمبحوثة: يقصد هـا مستوى تعليم المبحوثــــــ

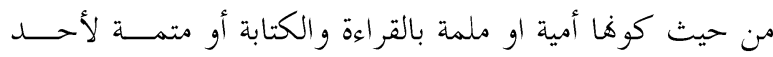

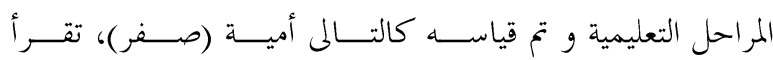

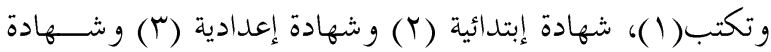
ثنانوية أو دبلوم(ع) وشهادة جامعية(0) (1). r- الحيازة المزرعية : يقصد ها بحموع المساحة الأرضية الزراعية

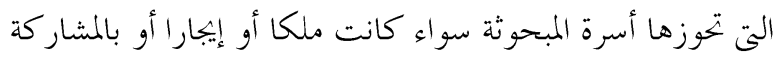
أوخليط من ذلك مقدرة بالفدان. ع - نوع الأسرة: يقصد بها إذا كانت أسرة المبحوتـــة بســيطة أو مر كبة معبر اعنها بإعطاء قيم رقمية للأسرة البسيطة (T) والأسرة

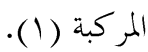
ه- السعة الأسرية : يقصد هـا عدد أفراد أسرة المبحوثة الــــين يعيشون معا في مسكن واحل ويشتر كون في معيشة اسـتهلاكية

$$
\text { واحدة وقت إجر اء البحث. }
$$

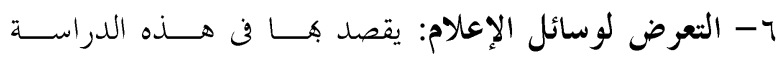

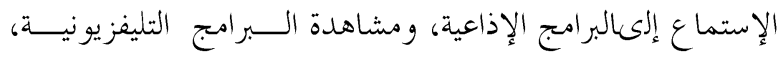

ويقرر بنك التنمية والإيتمان الزراعى أن المشروعات الريفيــة الصغيرة هى تلك المشروعات التي يمارسها المستثمر الصغير في مترله

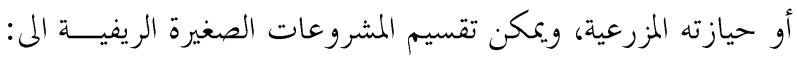
(1) مشروعات متناهية الصغر وهى التى يعمل هـا من ا- ه عامل،

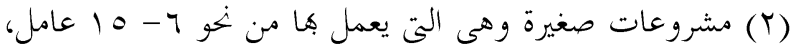

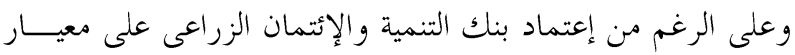
العمالة لتقسيم المشروعات الصغيرة، فإن هناك القيمة النقدية للتفرقة بين المشروعات المتناهية الصغر والمشروعات الصغيرة، إلا أن القيمة

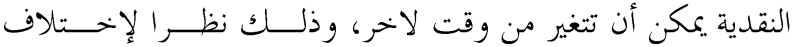
الأوضاع الإقتصادية والإجتماعية والتكنولوجية، وخلاصة القول أن

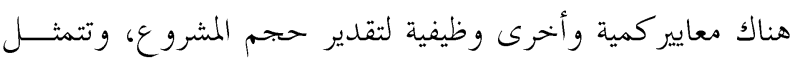

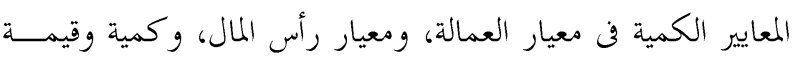
الإنتاج، وعدد الالات المستخدمة، وتتمثل المعــايير الوظيفيــة في أسلوب الإدارة والتنظيم المستخدم بالمشروع، والمستوى التكنولوجى

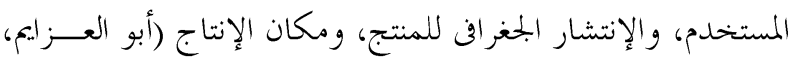
$\cdot(r+$. ثانيا: بعض الدراسات الإرشادية الزراعية ذات الصلة بموضـــوع

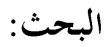
دراسة (الملاح، 99 99 ( )عن" الاحتياجات التمويليــة والتدريبيـة

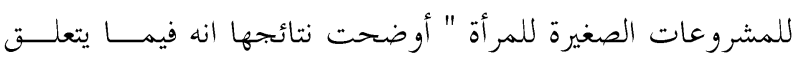

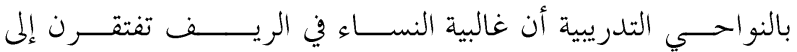
المـــعارف الكافية عن الصناعات الصغيرة التي يمكن أن تقوم المـــــأة

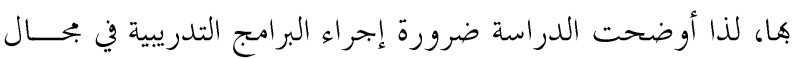

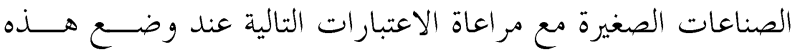

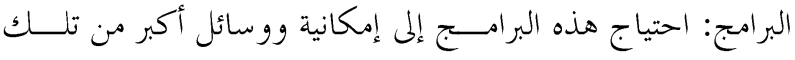
المتعلقة بالبرامج الاجتماعية والثقافية ومن تم يجب توفير الإمكانيات

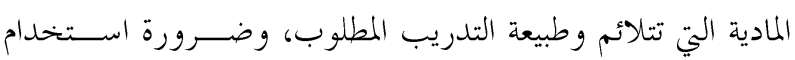
الأساليب الحديثة في التدريب وضرورة أن يتضمن البرنامج التدريي لتئي

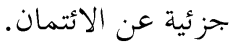

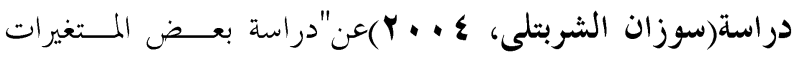

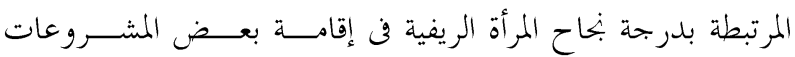

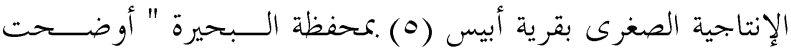


ا- درجة الإتجاه نحو المشروعات الصغيرة: يعــرف ألبــورت

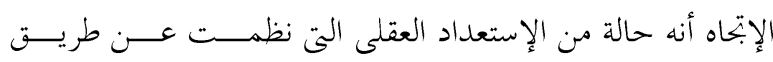

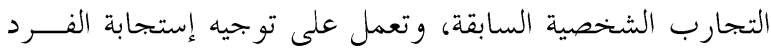

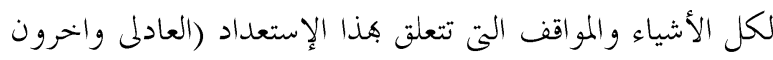

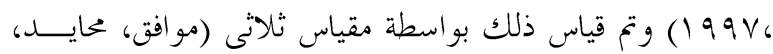

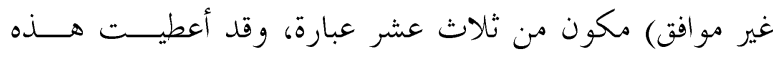

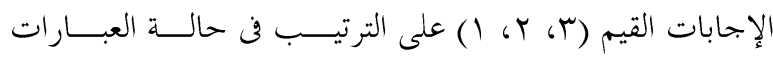

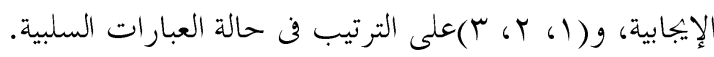
Y- المستوى المعرفى- التنفيذى الخاص بالتوصيات الفنية لتربية

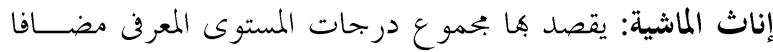

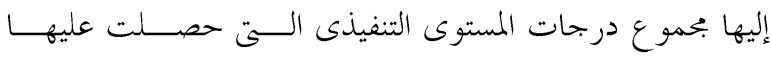

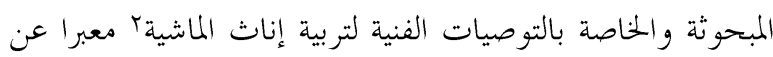

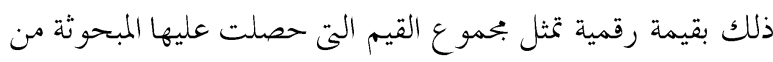

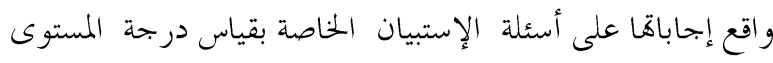
المعر فن و المستوى التنفيذى وإمكانية التنفيذ وذلك على النحو التالى: تعرف(Y)، ولاتعرف (صفر )، وتنفذ (Y)، ولا تنفذ(صفر )، سهلة

$$
\text { التنفيذ(Y)، و صعبة (صفر ). }
$$

وفقا لأهداف البحث وفى ضوء ما تم إستعر اضه من بحـــوث

ودراسات سابقة فإن هذه الدراسة تختبر الفروض البحثية التالية: الفرض الأول: توجد علاقة إرتباطية بين درجة إبتحاه المبحوثــات

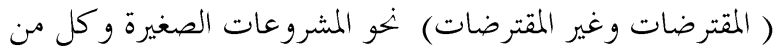

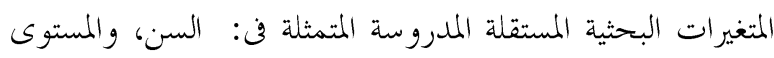

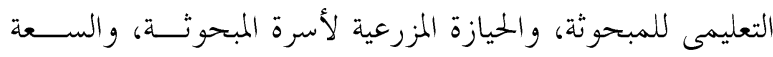

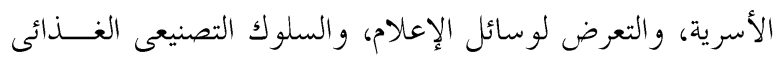

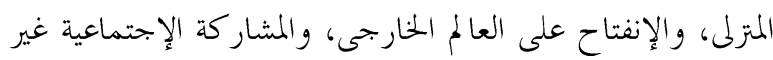
الرسمية، ودرجة القيادية، و المشار كة فن صنع القرارات الأسرية. الفرض الثالن : توجد علاقة إرتباطية بين المســـويات المعرفيـــة و التنفيذية والمعرفية- التنفيذية الخماصة بالتوصيات الفنية لتربية إنــاث لــاث

باتم الر جوع علأراء الأساتذة المتخصصين في النواحى الفنية العلمية وإلى الكتب العلمية
ومطالعة الصحف والمحلات وقد أعطيت ثلاث درجــات للتعــرض دائما، ودرجتان للتعرض أحيانا، ودرجة واحدة للتعرض نادرا. V- السلوك التصنيعى الغذائى المزتلى: يقصد به قدرة المبحوثة علي

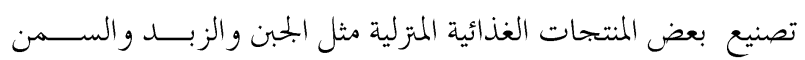

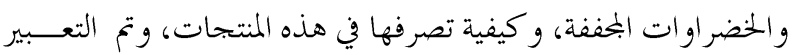
عن ذلك بقيم رقمية على النحو التالى: لاتعرف كيفيــة التصــيع

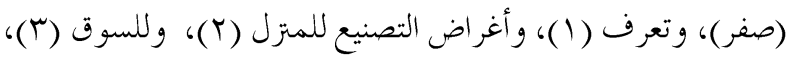

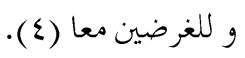
^- الإنفتاح على العالم الخارجى: يقصد به مدي قيام المبحوثة بزيارة

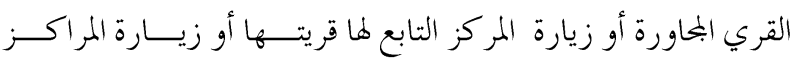
الأخرى داخل المحافظة أو زيارة محافظات أخرى أو زيــارة القــــاهرة

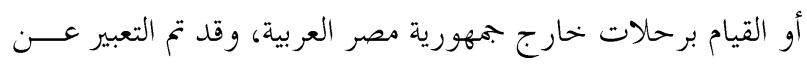

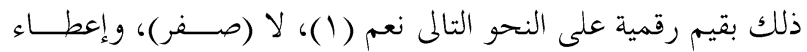

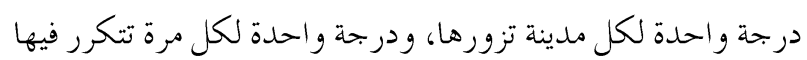

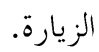

و- المثاركة الإجتماعية غير الرسمية: يقصد بها مدي قيام المبحوثة

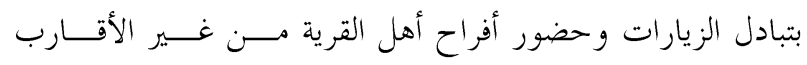

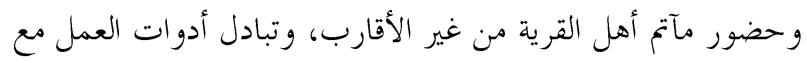

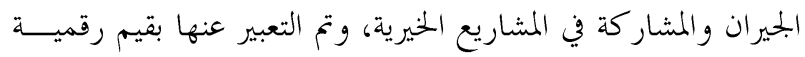

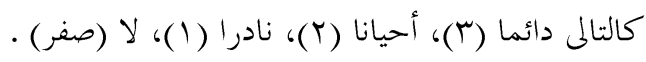
• ا- درجة القيادية: يقصد بها في هذا البحث درجة قيـادةالرأى

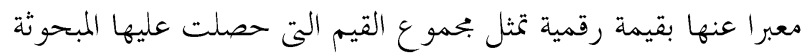

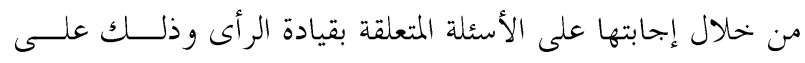

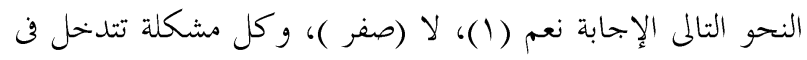
حلها تعطى درجة واحدة .

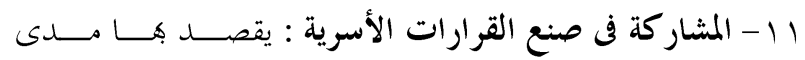
مشار كة المبحوثة في القرارات الأسرية معبرا عنها بقيمة رقمية تمثــلـل

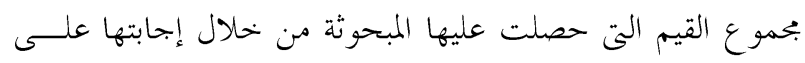
الأسئلة المتعلقة بالمشاركة و ذلك الثئ على النحو التالى دائما (ب)، أحيانا

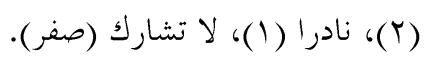

ب- المتغيرات التابعة وطرق قياسها: 
الشخصية لأفراد البحث وذلك بعد تصميم وإعـــداد إســتمارة

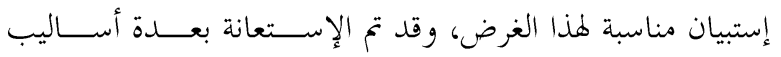

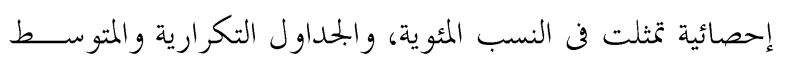

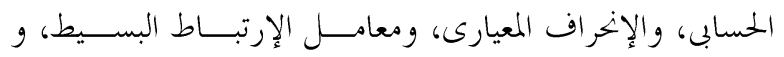
أسلوب التحليل الإنحدارى المتعدد المتدرج.

\section{النتائج ومناقشتها}

أولا: بعض الخصائص الشخصية والإقتصادية والإتصالية المميزة

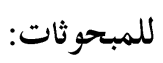

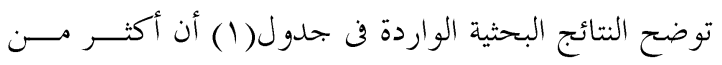

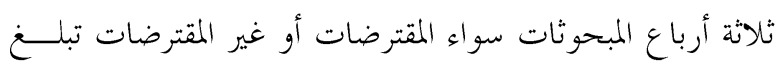

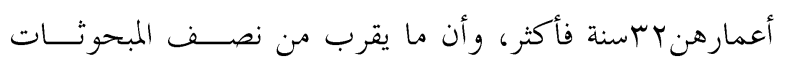

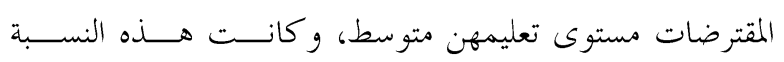

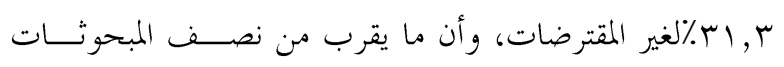

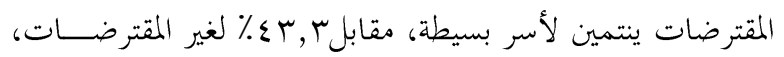

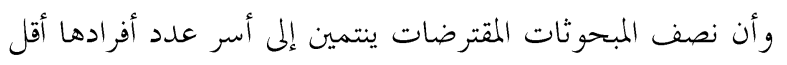

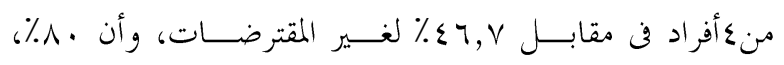

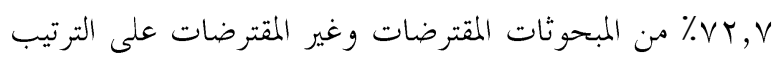

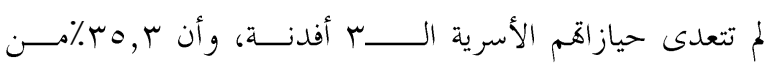

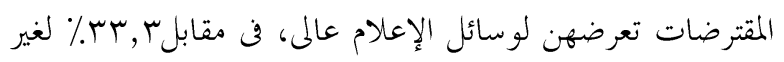

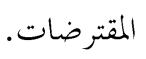

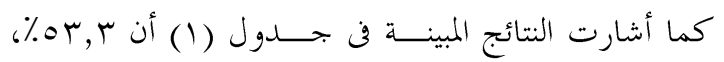

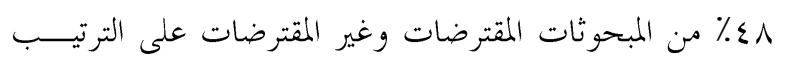

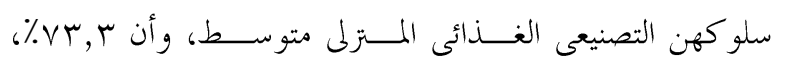

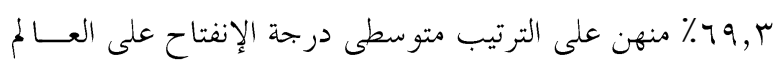

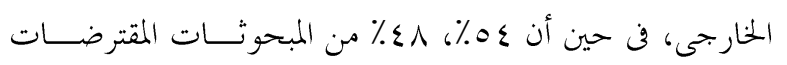

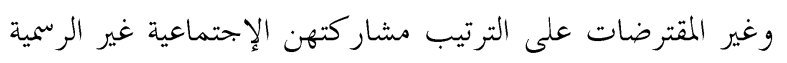

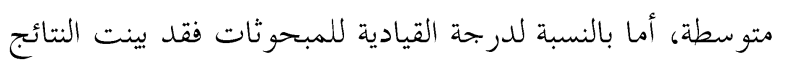

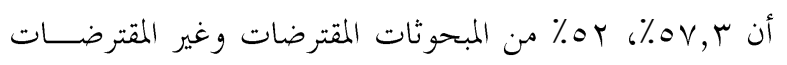

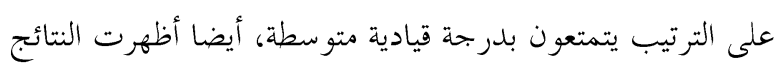

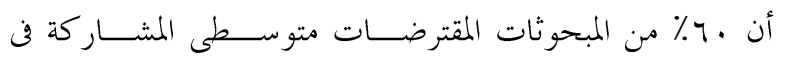

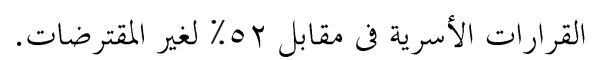

الماشية للمبحوثات المقترضات و أى من المتغيرات البحثية المســتقلة

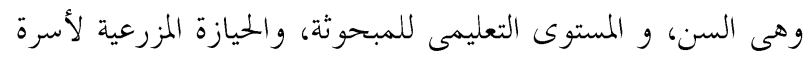

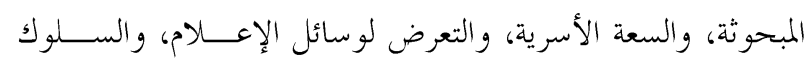

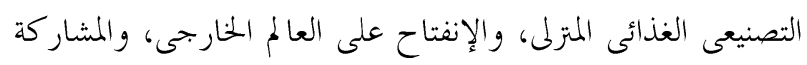

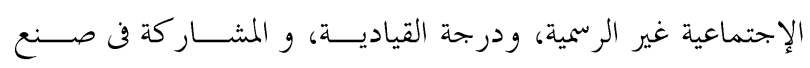

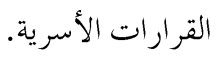
وسوف يتم اختبار مدى صحة هــــهـ الفـــروض فن صــورةها الصفرية.

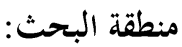

تتحدد منطقة البحث في قريتين الأولى قرية ديبونو. بمركز إدكو

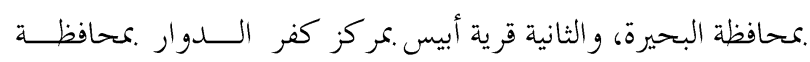

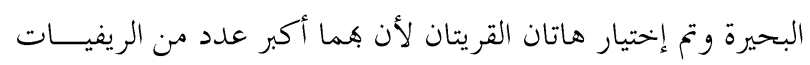

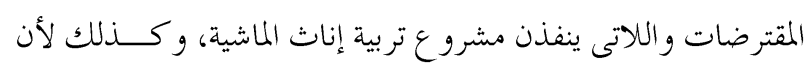

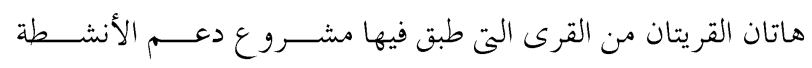

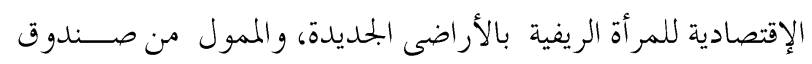

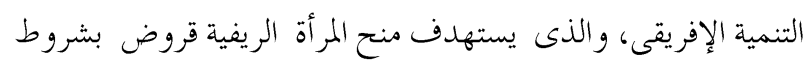
ميسرة.

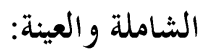

ضمت شاملة هذا البحث جميع النساء الريفيات الحاصــلات على قروض من بنك التنمية والإئتمان الزراعى لتنفيذ مشروع تربية

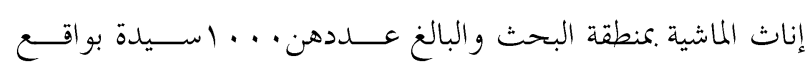

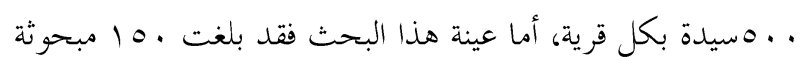

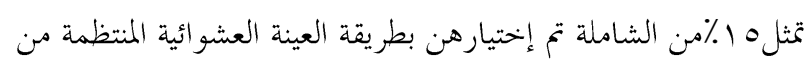

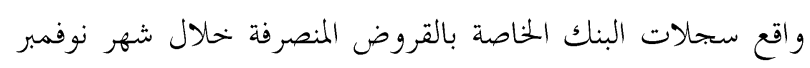

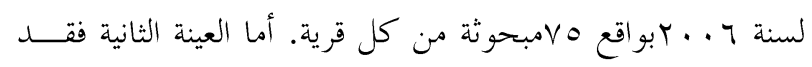

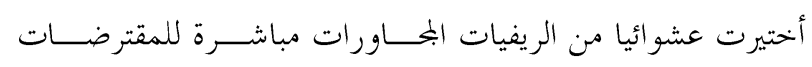

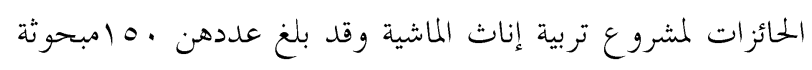

$$
\text { أسلوب اقع Vo مبحوثة من كل قرية. }
$$

تم الحصول على البيانات البحثية من خلال الإستبيان بالمقابلة 
جدول الـ توزيع المبحوثات وفقا لبعض الخصائص الشخصية والإقتصادية والإتصالية المميزة لهن

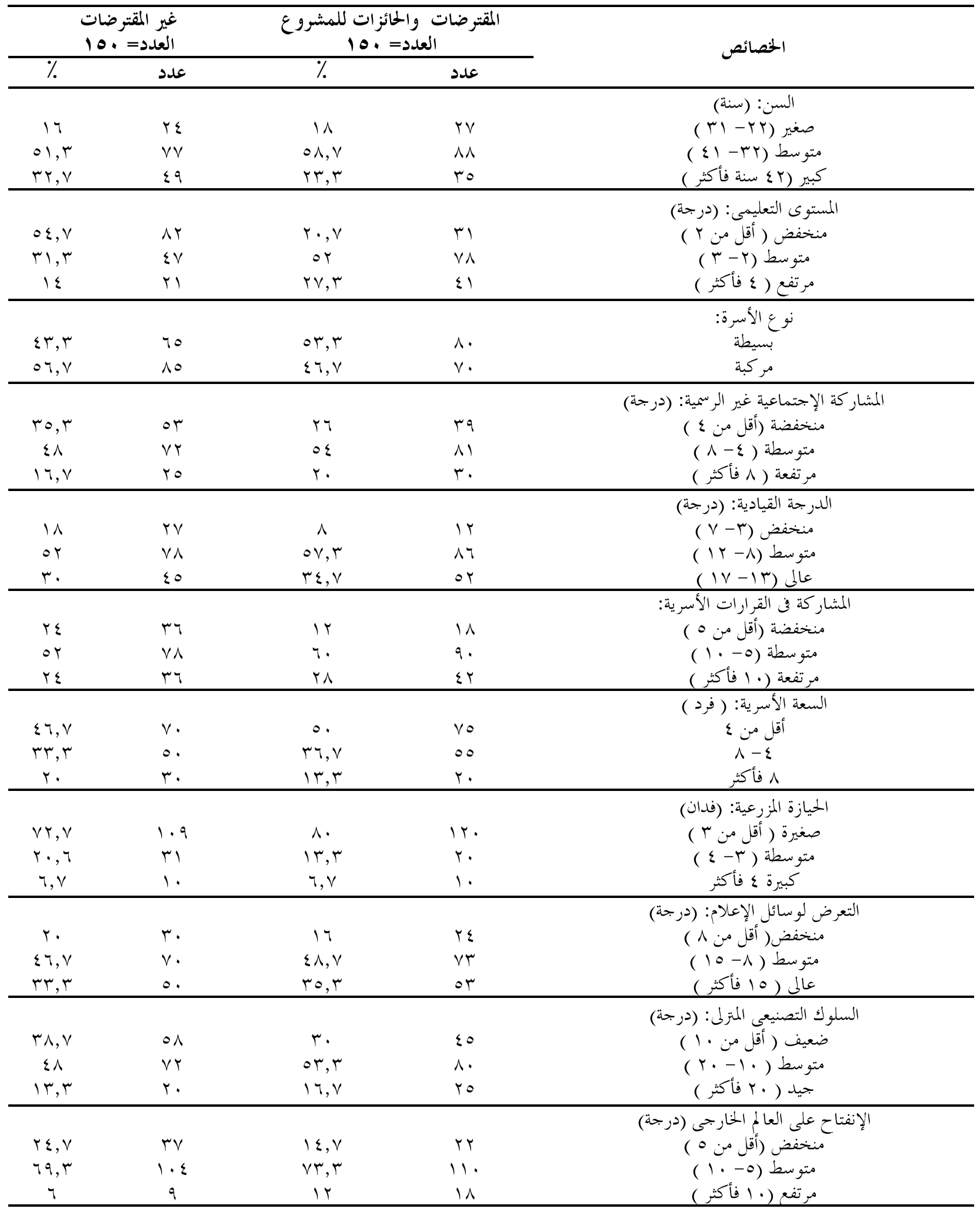


ا -المستوى المعرفى للمبحوثات المقترضات للتوصيات الفنيــة

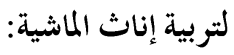

ان دراسة المستوى المعرفى يسهم في بناء بـــــامج إرشــادية

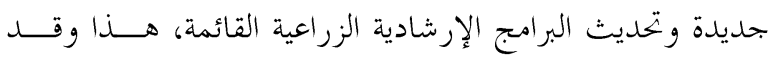
تراوح المدى النظرى بين(صفر - r • (1) درجة، ومن و اقع إجابات

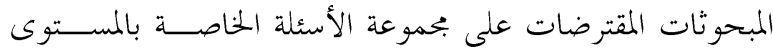

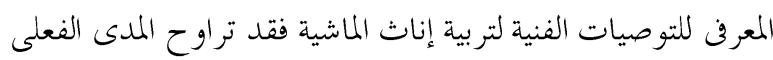

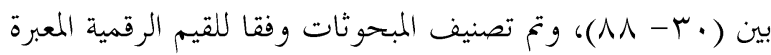

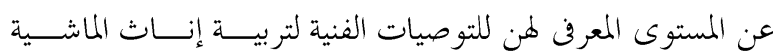

جدول(乏)

يتبين من جدول(ع) ان ما يزيد عن ثلاثة أرباع المبحوثــات

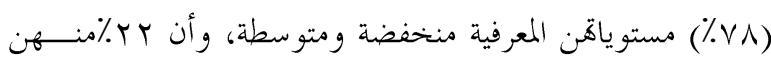

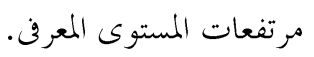

ثانيا: مستوى إتجاه المبحوثات المقترضات وغير المقترضات نهـــو المثروعات الصغيرة: تم تصنيف المبحوثات وفقا لمستوى إبتاهاهن نهو المشروعات

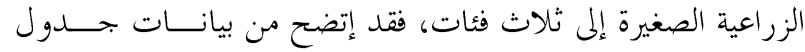

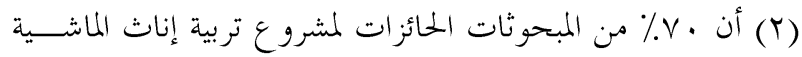

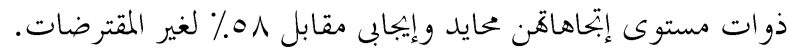
الفروق بين درجات إتجاه المبحوثات المقترضات وغير المقترضات

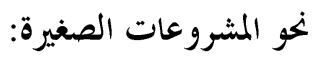
يتضح من بيانات جدول(r) وجود فرق معنوى، عند مستوى

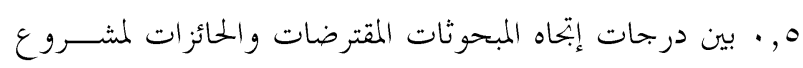

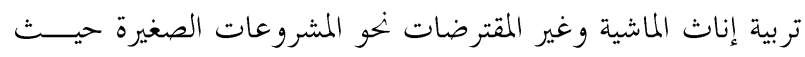

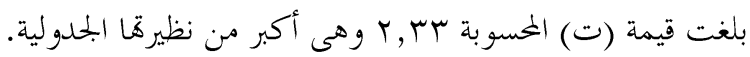
ثالثا: المستويات المعرفية والتنفيذية والمعرفية التنفيذية للمبحوثات المقتر ضات الخخاصة بالتوصيات الفنية لتربية إناث الماشية جدول Y .مستوى إتجاه المبحوثات المقتر ضات وغير المقتر ضات نحو المشروعات الصغيرة

\begin{tabular}{|c|c|c|c|c|}
\hline \multicolumn{2}{|c|}{ غير المقترضات } & \multicolumn{2}{|c|}{ المقترضات الحائز ات للمشروع } & \multirow{2}{*}{ مستوى الإتجاه ( درجة ) } \\
\hline$\%$ & عدد & $\%$ & عدد & \\
\hline$\varepsilon r$ & Tr & $r$. & $\varepsilon 0$ & سبى ( 1 (Y - ) \\
\hline$\varepsilon \vee, r$ & vi & or, r & $\wedge$ & عحايد ( سT- \\
\hline $1 \cdot, \mathrm{V}$ & 17 & $17, \mathrm{~V}$ & ro & إيجاب ( r د درجة فأكثر ) \\
\hline $1 \ldots$ & 10. & $1 \ldots$ & 10. & الجموع ع \\
\hline
\end{tabular}

جدول r. الفروق بين درجات إتجاه المبحوثات المقترضات لمشروع تربية إناث الماشية وغير المقترضات نحو المشروعات الصغيرة

\begin{tabular}{|c|c|c|c|c|}
\hline قيمة (ت ) & الإنحر اف المعيارى & المتوسط الحسابي & حجم العينة & المبحوثات \\
\hline \multirow{2}{*}{${ }^{\star} T, r \mu$} & $T, Y T_{1}$ & rฯ, & 10. & المقتر ضات \\
\hline & $0, M Y I$ & $r \mu, 1 r \varepsilon$ & 10. & غير المقترضات \\
\hline
\end{tabular}

جدول ع ـ المستوى المعرفى للمبحوثات المفترضات للتوصيات الفنية لتربية إناث الماشية

\begin{tabular}{|c|c|c|}
\hline$\%$ & العدد - العد & المستوى المعرفى للتوصيات الفنية لتربية إناث الماشية \\
\hline$\varepsilon 1, \varepsilon$ & Tr & منخفض (·r - م ( ) \\
\hline r & 00 & متوسط ( .0. - V. ) \\
\hline rt & r & 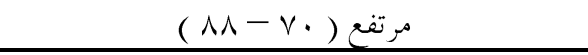 \\
\hline $1 \ldots$ & 10. & البجموع \\
\hline
\end{tabular}




\section{الخصائص المميزة لهن: - المئ}

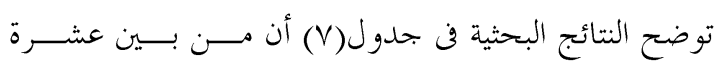

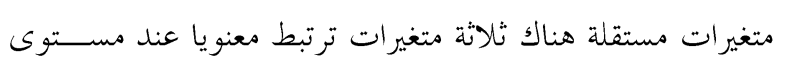

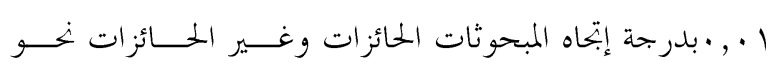

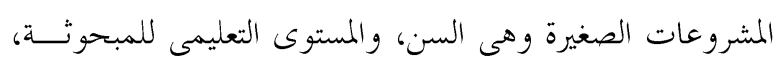

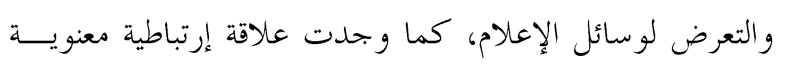

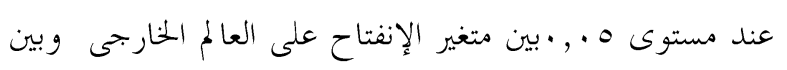

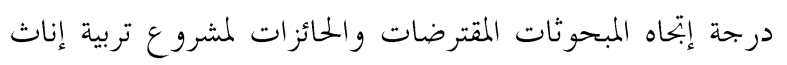

$$
\text { الماشية نخو المشروعات الصغيرة. }
$$

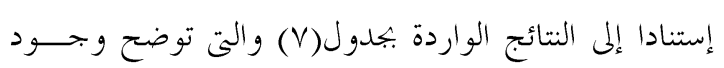

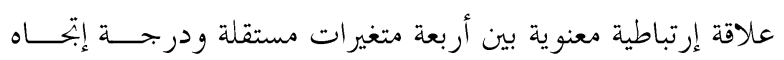

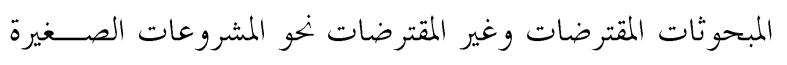

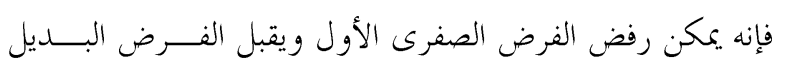

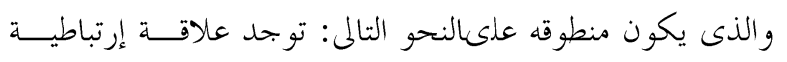

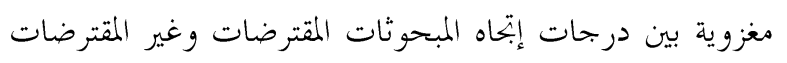

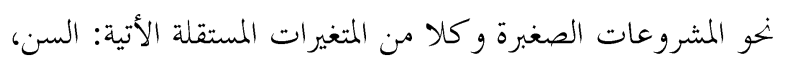

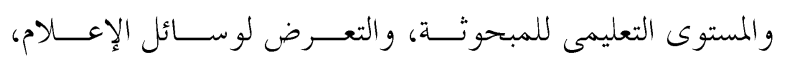

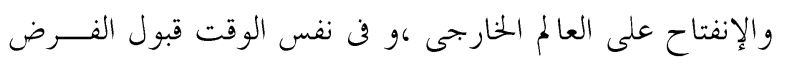

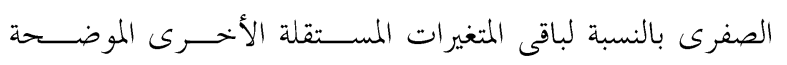
بجدول(V)

ب-المستوى التنفيذى للمبحوثات المقترضات للتوصيات الفنيــة

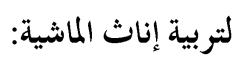

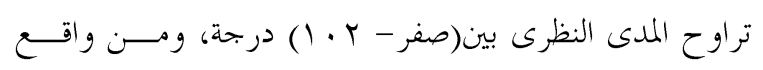

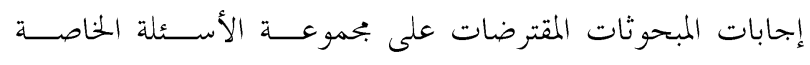

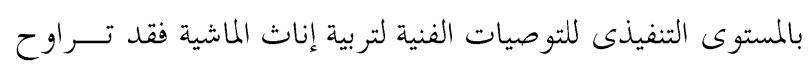

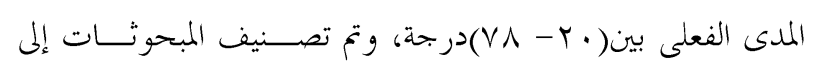

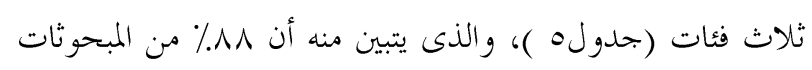

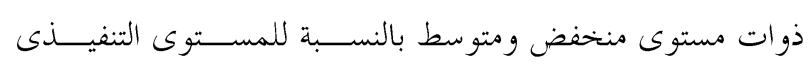
للتوصيات الفنية لتربية إناث الماشية. r-المستوى المعرفى-التنفيذى للمبحوثات المقترضات للتوصيات

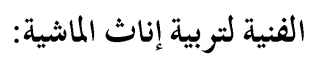

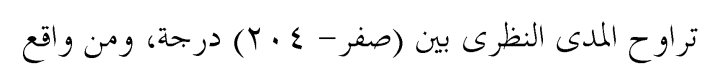

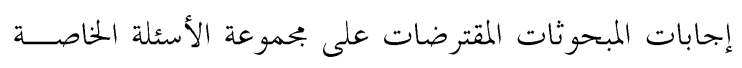

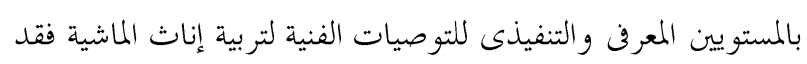

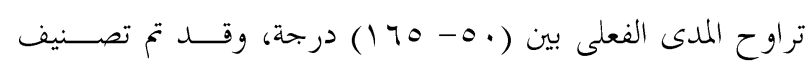

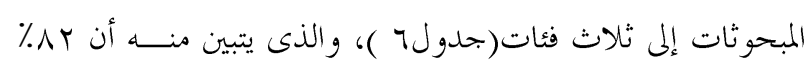

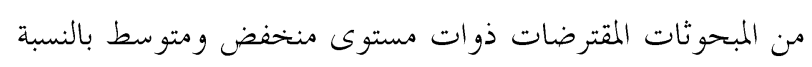
للمستوى المعر في والتنفيذي للتوصيات الفنية لتربية إناث الماشية.

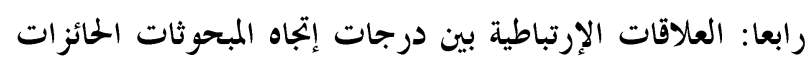

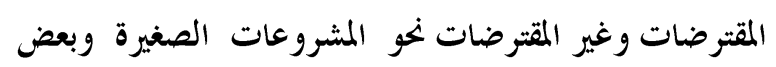

\begin{tabular}{|c|c|c|}
\hline$\%$ & 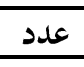 & المستوى التنفيذى للتوصيات الفنية لتربية إناث الماشية(درجة) \\
\hline$\varepsilon \wedge$ & Vr & منخفض (·r - - ع ) \\
\hline$\varepsilon$. & 7. & متوسط (·ـ - . ד ) \\
\hline ir & 11 & مر تفع (. V \\
\hline $1 \ldots$ & 10. & البجموع البو \\
\hline
\end{tabular}

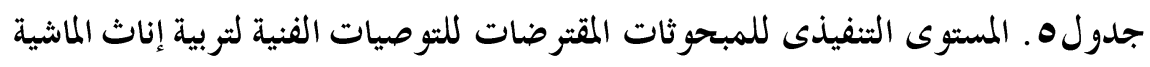

\begin{tabular}{|c|c|c|}
\hline$\%$ & عدد ( عد & المستوى المعرف - التنفيذى للتوصيات الفنية لتربية إناث الماشية(درجة) \\
\hline$\varepsilon \varepsilon$ & 74 & منخفض (.0. - . 9 ) \\
\hline r & ov & متوسط (.q - . r (1) \\
\hline 11 & TV & مرتفع (·r (1/170-) \\
\hline $1 \ldots$ & 10. & الجموع ع الجمو \\
\hline
\end{tabular}

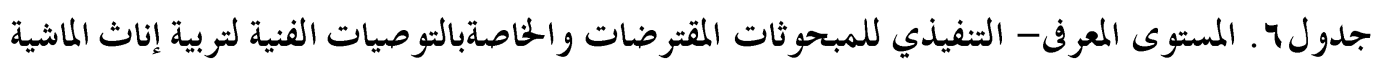


جدول V. معاملات الإرتباط البسيط بين درجة إتجاه المبحوثات المقترضات وغير المقترضات نهو المشروعات الصغيرة وبعض

المتغيرات المستقلة

\begin{tabular}{|c|c|c|}
\hline \multicolumn{2}{|c|}{ معامل الارتباط البسيط } & \multirow{2}{*}{ المتغير ات المستقلة } \\
\hline غير المقترضات & المقتر ضات & \\
\hline ****, , $701 \%-$ & ***, VYO- & العمر | - العر \\
\hline$\cdot, 1 \% \wedge t$ & $\cdot, \cdot T I r$ & السعة الاسرية \\
\hline ***, TrYo & ****,, $00 \leqslant$ & المستوي التعليمي للمبحوثة \\
\hline., $1 \cdot 1 r$ & $\cdot, 1 \leq 7$ & الحيازة الزراعية \\
\hline שr. & **⿻丷木 $\cdot, V Y r$ & التعرض لوسائل الاعلام \\
\hline., $1 T \circ \varepsilon$ & $\cdot, r q r$ & السلوك التصنيعي الغذائي المترلي \\
\hline$*, 01 V T$ & $*, T \cdot r$ & الانفتاح علي العالم الخارجي \\
\hline$\cdot, r \ldots$ & $\cdot, 1 r v$ & المشاركة الاجتماعية غير الرسمية \\
\hline$\cdot, \cdot$.MY & .,$Y T \leq$ & الدرجة القيادية \\
\hline., $1 \leq 0$. & $\cdot, \cdot r Y$ & المشار كة في القرارات الاسرية \\
\hline
\end{tabular}

وإزاء تلك النتيجة فإنه يمكن رفض الفرض الصفرى الثــانى ويقبل الفرض البديل والذى ينص على أنه "توجد علاقة إرتباطية

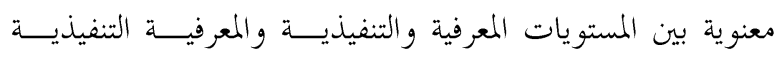

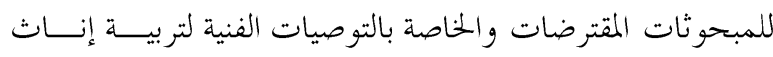

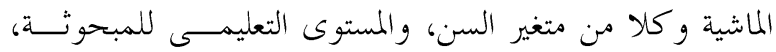

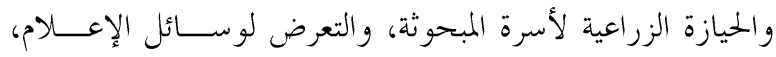
و الدرجة القيادية" وفن نفس الوقت قبول الفرض الصفرى بالنسبة

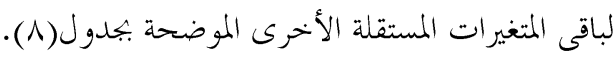

العلاقات الإرتباطية بين المستويات المعرفية والتنفيذية والمعرفيسـة التنفيذية للمبحوثات المقترضات و الخاصة بالتوصيات الفنية لتربية إناث الماشية وبعض الخصائص المميزة لفن: تظهر النتائج البحثية في جدول(^) أن هناك علاقـــة إرتباطيـــة

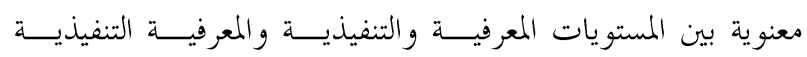

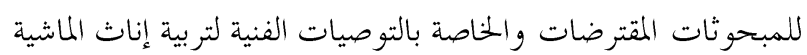
و كلا من متغيرات العمر، و المستوى التعليمى للمبحوثة، والحيــازة

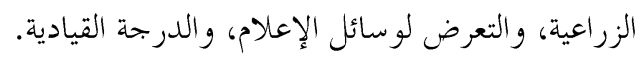

جدولهـ العلاقات الإرتباطية بين المستويات المعرفية والتنفيذية والمعرفية التنفيذية للمبحوثات المقترضات الخخاصة بالتوصـيات الفنية لتربية إناث الماشية وبعض الحُصائص المميزة لهن

\begin{tabular}{|c|c|c|c|}
\hline 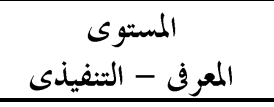 & المستوى التنفيذى & المستوى المعرفى & المتغيرات المستقلة \\
\hline معامل الإرتباط البسيط & معامل الإرتباط البسيط & معامل الإرتباط البسيط & \\
\hline${ }^{\star} \cdot, \varepsilon \leqslant Y-$ & $\star,, \Sigma r r-$ & ^., Оr. - & 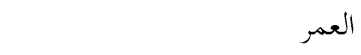 \\
\hline$\cdot, \cdot \wedge 1$ & $\cdot, \cdot \varepsilon V$ & $\cdot, r \cdot 1$ & السعة الأسرية \\
\hline$\star \star,, \varepsilon \vee 1$ & $\star \star ., \varepsilon \mu ч$ & $\star \star,,\{0\}$ & المستوى التعليمى للمبحوثة \\
\hline$\star_{\cdot}^{\star}, r \wedge \vee$ & $\star,, r 71$ & $\star, r q 1$ & الحيازة الزراعية \\
\hline${ }^{\star} \cdot, \varepsilon r r$ & ${ }^{\star}$, , $\Sigma$ r. & $\star{ }^{\star}, \varepsilon, 1$ & التعرض لوسائل الأعلام \\
\hline$\cdot, \cdot \mu_{1}$ & $\cdot, \cdot \leq r$ & $\cdot, \cdot$ rr & السلوك التصنيعى الغذائى المترلى \\
\hline$\cdot, 1 \cdot r$ & $\cdot, 111$ & $\cdot, 1 r$. & الإنفتاح على العالم الخارجى \\
\hline 更 & $\cdot, 1 r$. & $\cdot, 1 \cdot 1$ & المشار كة الإجتماعية غير الرسمية \\
\hline 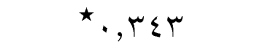 & ${ }^{\star} \cdot, \operatorname{RT}$ & ${ }^{\star}$, ror & الدرجة القيادية \\
\hline$\cdot, 1 \cdot r$ & $\cdot, 1 \cdot 1$ & $\cdot, 1 \cdot r$ & المشار كة في القرارات الأسرية \\
\hline
\end{tabular}


المتغيرات المستقلة بعضها وبعض والداخلــــة في تحليـل الإخــــــار

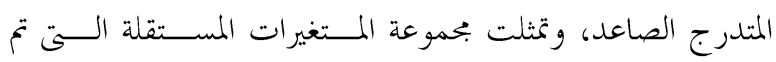

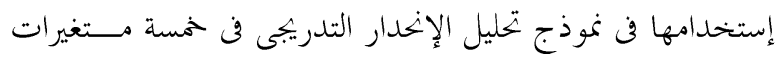
الإعلام، والدرجة القيادية، و الحيازة الزراعية.

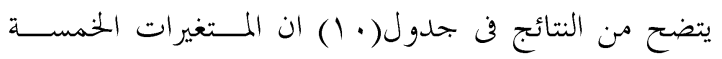

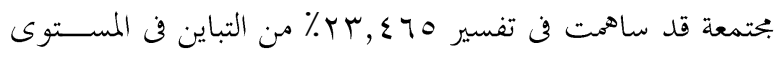
المعرفى - التنفيذى للمبحوثات المقترضات الخاص بالتوصيات الفنية

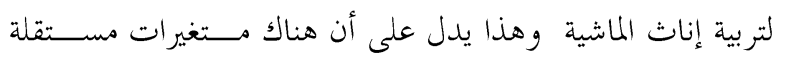

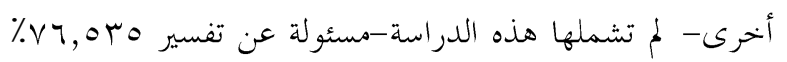
من هذا التباين، وبإختبارمعنوية معامل الإنحدار بإستخدام إختبار

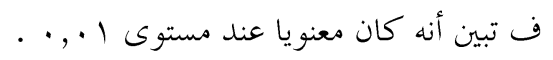
خامسا: بعض المشكلات التى واجهت المبحوثات المقترضــات المنفذات لمشروع تربية إناث الماشية:

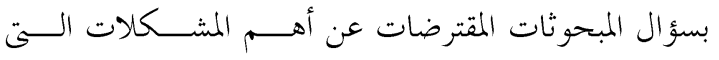

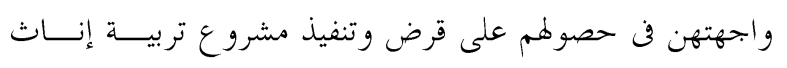

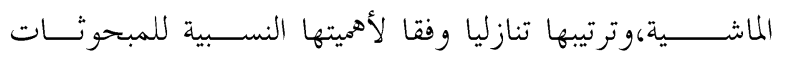

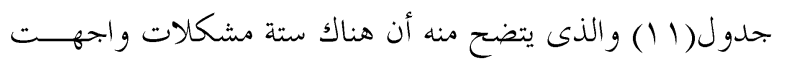
المبحوثات فى تنفيذ مشروع تربية إناث الماشية كان من أهمها عدم

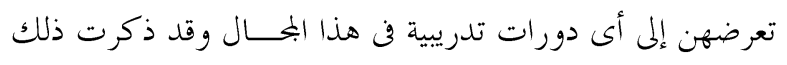

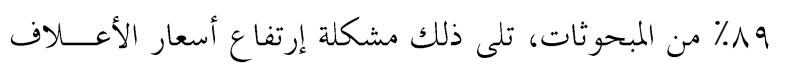

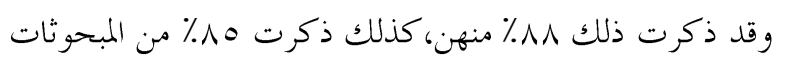

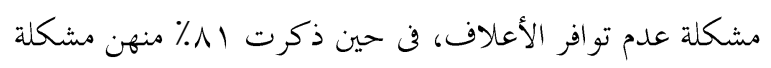

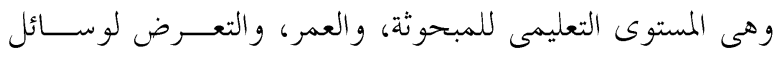

مدى التباين في المستويات المعرفيــة- التنفيذيــة للمبحوثــــات

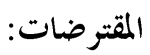
توضح نتائج انتبار مربع كاى جدول(9) وجهـود فـــروق

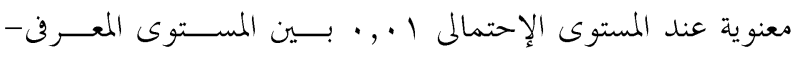

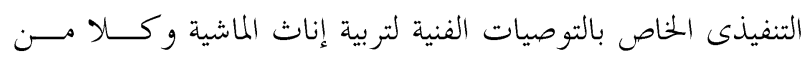

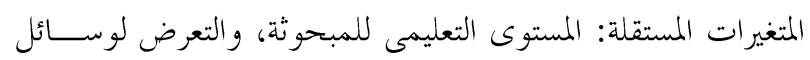
الإعلام، والدرجة القيادية.

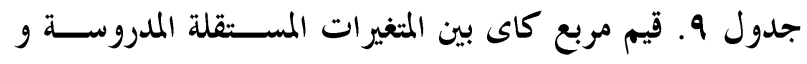
المستوى المعرفى- التنفيذى للمبحوثات المقترضات لتربية إنـاث لــاث

\begin{tabular}{|c|c|}
\hline قيم مربع كاى الخسوبة & المتغيرات المستقلة \\
\hline$\star \star \Sigma q, \mu r,$. & المستوى التعليمى للمبحوثة \\
\hline$r, .0$ & \\
\hline$\star \star|Y, r|$ & التعرض لو سائل الأعلا \\
\hline$V, r_{O}$ & السلوك التصنيعى الغذائى المتزلى \\
\hline$\{, 71$ & الإنفتاح على العالم الخارجى \\
\hline $9, \pi 1$ & المشار كة الإجتماعية غير الرسمية \\
\hline$\star \star \quad r, r \leq$ & الدرجة القيادية \\
\hline$T, V Y$ & المشار كة في القرارات الأسرية \\
\hline
\end{tabular}

مدى إسهام المتغيرات المستقلة المدروسة ذات الإرتباط المعنـــى

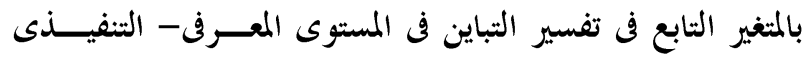

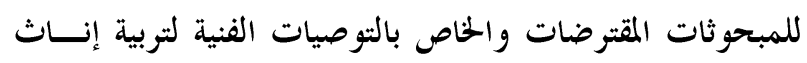
الماشية كمتغير تابع:لتحقيق ذلك فقد تم إجراء تحليل الإنحدار المتعــدد المتـــدرج الصاعد بعد دراسة مصفوفة الإرتباط البسيط بين المتغيرات المستقلة إلماء والتى تم التأكد من خلالها من عدم وجود علاقة إرتباطية خطية بين بلهين

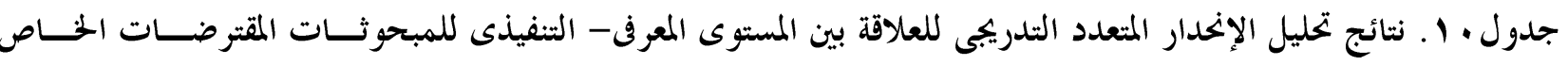
بالتوصيات الفنية لتربية إناث الماشية والمتغيرات المستقلة ذات الإرتباط المعنوى بالمتغير التابع

\begin{tabular}{|c|c|c|c|c|}
\hline لإختبارمعنوية في الإنحدار & \% للتباين المفسر & المفسر للمتغية للتباين & معامل الإرتباط & المتغير الداخل فى التحليل \\
\hline$* * * * 1 \wedge, 1 \leqslant r$ & $9,\{Y\}$ & $q, \sum Y 1$ & $\cdot, r \ldots \varepsilon$ & المستوى التعليمى \\
\hline **** $\mid \vee, \wedge T V$ & $0, T Y \varepsilon$ & $1 \leqslant, V \leqslant 0$ & . & العمر \\
\hline **⿻丷木 $|7, \varepsilon| \varepsilon$ & $r, q \cdot r$ & $\mid \wedge, T \leqslant \vee$ & $\cdot,\{q \vee \wedge 1$ & التعرض لوسائل الإعلام \\
\hline **** $\mid 0, r .1$ & $r, \wedge)$. & $r 1, \Sigma \circ V$ &., oVVAr & الدرجة القيادية \\
\hline *** $\wedge, १ \wedge \wedge$ & $r, \cdots \wedge$ & $r \mu, \Sigma \Upsilon_{0}$ &., $0907 \mathrm{~V}$ & الحيازة الزراعية \\
\hline
\end{tabular}


جدول ل1 ا. بعض المشكلات التى واجهت المبحوثات المتترضات المنفذات لمشروع تربية إناث الماشية

\begin{tabular}{|c|c|c|}
\hline 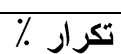 & المشكلات & \\
\hline 19 & عدم التعرض لأى دورات تدريبية في هذا البحال . & - \\
\hline$\wedge \wedge$ & إرتفاع أسعار الأعلاف . . . & - \\
\hline 10 & عدم تو افر الأعلاف . & - \\
\hline$\wedge$ & عدم وجود مصدر للمعلومات المساعدة على التطبيق . & - \\
\hline$\wedge$. & عدم معرفة أعراض الإصابة بالأمر اض المختلفة وكيفية الوقاية منها. & - \\
\hline ov & عدم تو افر النشر ات الفنية التي تتعلق بتربية إناث الماشية & - \\
\hline
\end{tabular}

التباين للمستوى المعرفى-التنفيذى للتوصيات الفنية لتربيــة

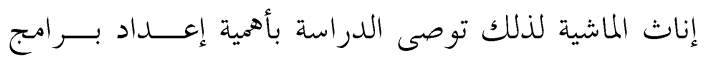

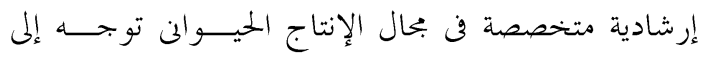

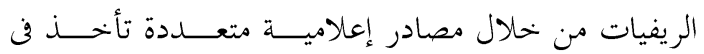

$$
\text { الإعتبار هذه المتغيرات. }
$$

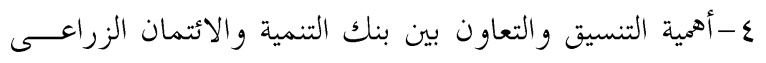

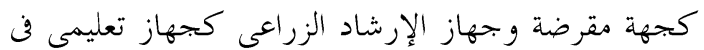

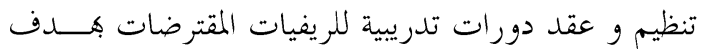
رفع المستويات المعرفية- التنفيذية لهن فن بحال تربية إنـاثـاث

$$
\text { الماشية. }
$$

ه-دعم الدور الإرشادى في العمل على إيجاد حلول للمشكلات

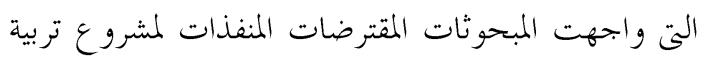

$$
\text { إناث الماشية. }
$$

ج-ضرورة إعداد برامج إرشادية ودورات تدريبية مــن قبــل

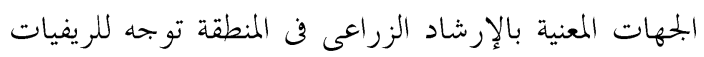

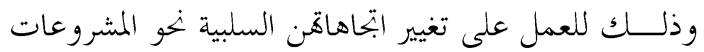

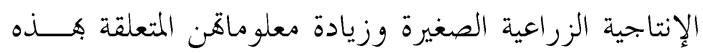

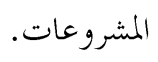

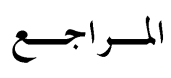

\section{أولا: المراجع بالغة العربية:-}

1- أبو العزايم، محمد جمال ماضى(دكتور): دور المشروعات الصغيرة

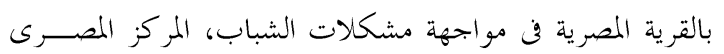

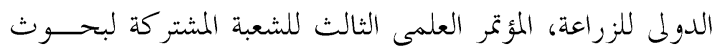

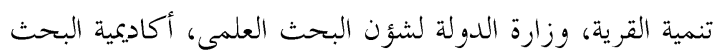

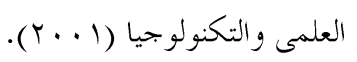

عدم وجود مصدر للمعلومات المساعدة على التطبيق، وأخيرا

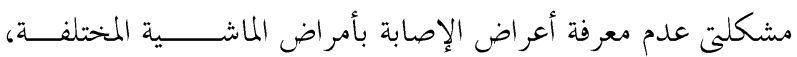
وعدم توافر النشرات الفنية التئ تتعلق بتربية إناث الماشية. هذا وقد ذكرت المبحوثات بعض المقترحات للتغلب على تلك

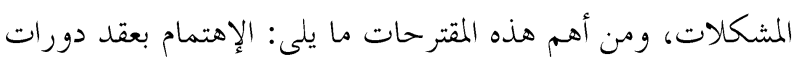

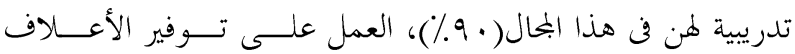

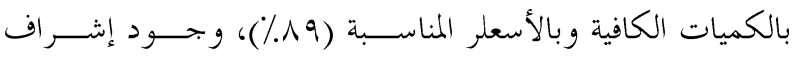

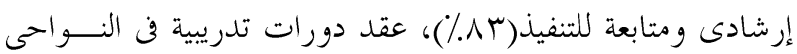

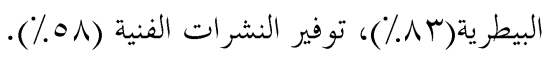

إنطلاقا مما أسفرت عنه الدراسة من نتائج بكثية، وفن ضوء مقتضيات

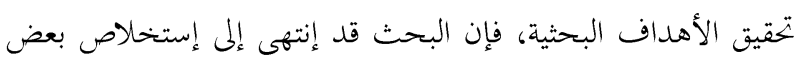

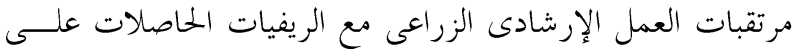
قروض من بنك التنمية والإئتمان الزراعى لتنفيذ مشروع تربية إناث الماشية وغير المقتر ضات والتي يمكن بلورةتا في النقاط التالية: 1-أوضحت نتائج البحث إنخفاضا فن المستويات المعرفية والتنفيذية

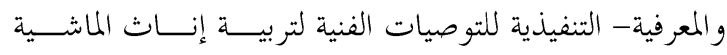
للمبحوثات المقترضات والمنفذات لمشروع تربية إناث الماشية

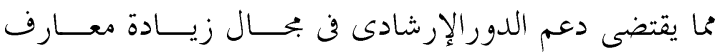
المبحوثات الخاصة هذه التوصيات.

ץ-أهمية إعداد برامج إرشادية متخصصة في بحال الإنتاج الحيوانى

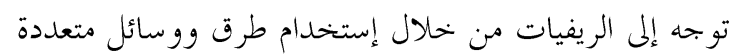

$$
\text { تتلائم مع طبيعة ووضع المرأة الريفية. }
$$

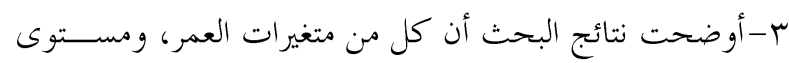

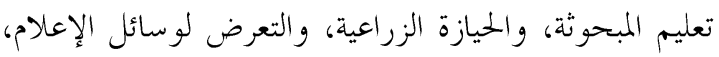

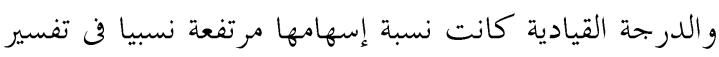




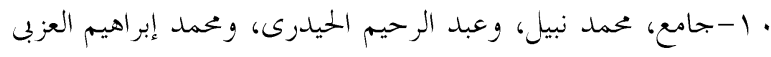

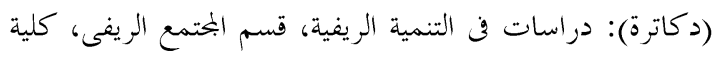

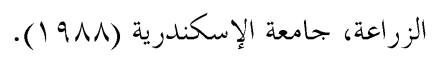

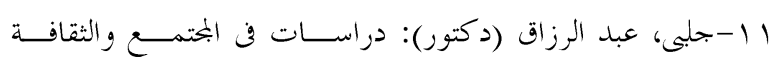

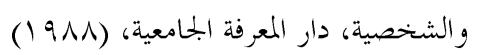
r ا ا- شاهين، زينب (دكتورة) المرأة المصرية والمشروعات الصــغيرة،

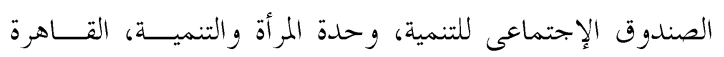

$$
\text { . ( . . I) }
$$

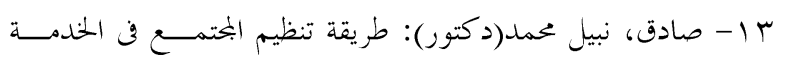

$$
\text { الإجتماعية، جامعة حلوان (ب.... (Y). }
$$

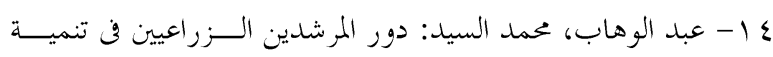

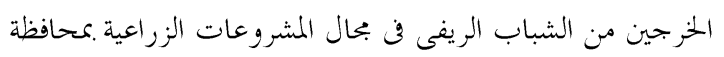

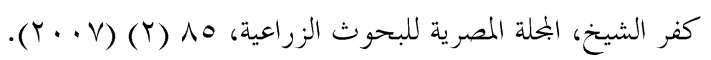
1 1 - عمر، أحمد محمد (دكتور): حاجة الشباب الريفى إلى الإرشــاد

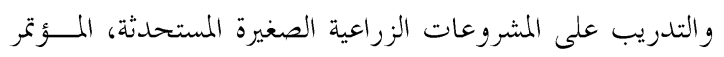

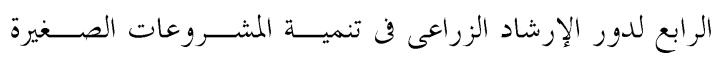

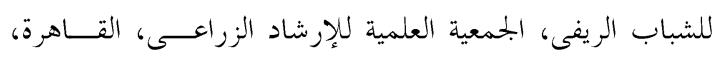

$$
.(1999) 1 \cdot / r)-r .
$$

ج ا - فرج، محمد سعيد(دكتور): البــناء الإجتماعى و الشخصية، دار

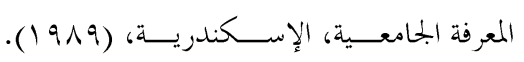

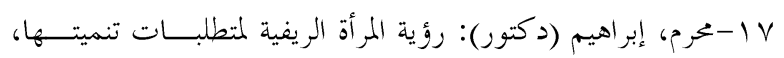

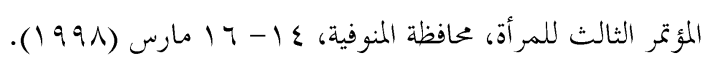

$$
\text { ثانياً: المر اجع بالغة الإنجليزية:- }
$$

1. Danber ,Roslynand Cain ,Melinedal : Women and Technological Change in Developing Countries, West View Press ,Inc and American Association for Advacement of Science, . N . W ., 1981.

2- Gibson, T .I . Ivancevich ,J . M . and Donnelly ,J. H . Organization Behavior, Processes, Business, Publications Inc . $3^{\text {rd }}$ edition, New York 1979 .
Y- أبو حطب، رضا عبد الخالق (دكتور): افاق العمل الإرشــادى في

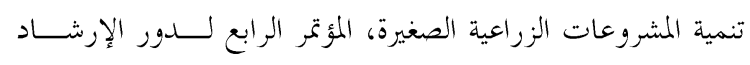

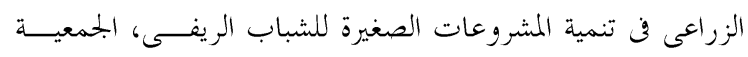

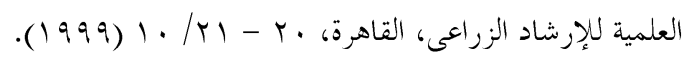
ب- الشربتلى، سوزان إبراهيم (دكتورة): دراسة بعض المتغيرلت المرتبطة

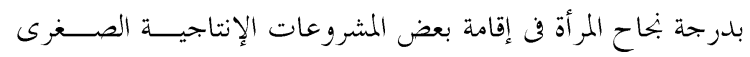

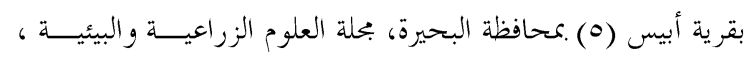

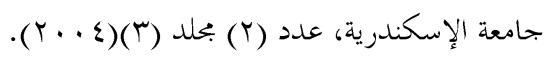

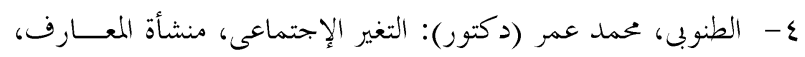
الإسكندرية (1997 (199).

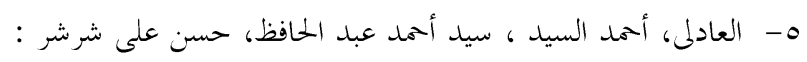

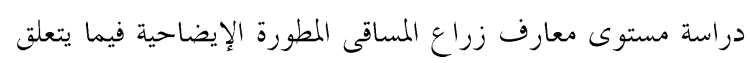

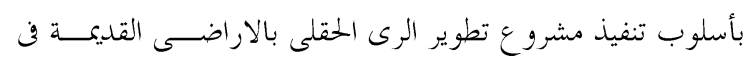
مركزي سيدى سالم ومطوبس بمحافظة كفر الشيخ ودور الأرشاد

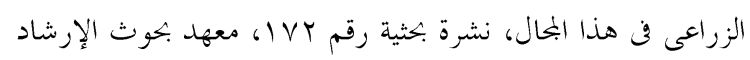

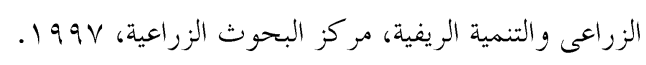
؟- الملس القومى للمرأد: مكافحة الفقر من خلال التمكين الإقتصادي

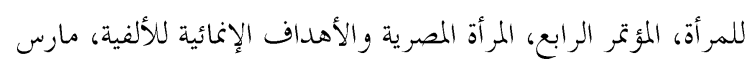

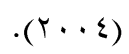

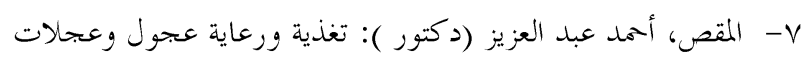

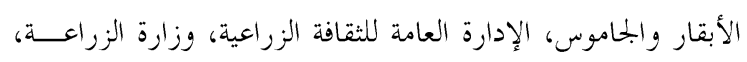

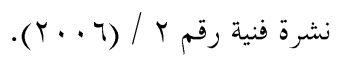

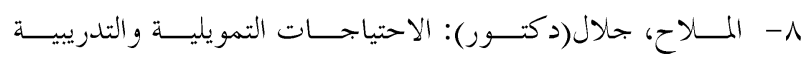

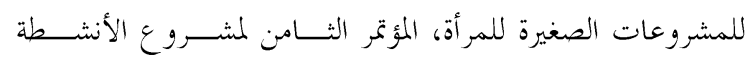
الإنتاجية للسيدات المنتفعات بالأراضى الجديدة، سبتمبر (1997 (1).

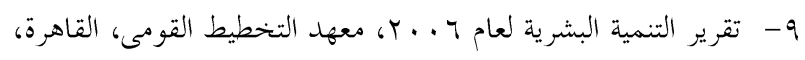

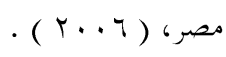




\title{
SUMMARY \\ Prospectives of Agricultural Extension Among Rural Debtors and Non Debtors Women's from Agricultural Credit and Development Bank for Execute Heifer Development Project in Some Villages in El-Beheira Governorate
}

\begin{abstract}
Amel.Fayed
This research aims mainly at studying prospective of agricultural extension among rural debtors and non debtors women's from Agricultural Credit and Development Bank to execute heifer development project in some villages in EL-Beheira governorate . This research was conducted in Abies village in Kafr Eldwar distract and Dybono village in Edco distract in El- Behira governorat.

A random sample consisted of 150 respondants representing debtors women and anothers 150 non debtors women was slected and the research data were collected through personal interview questionnaire prepared for this purpose. Several statistical methods were used in analyzing and presenting data such as: percentages, repeating tables, simple correlation, regression analysis.

The most important findings are as follows:

$1-70 \%, 58 \%$ of debtors and non debtors respondents have positive and neutral attitudes levels to small project generally.

$2-82 \%$ of debtors respondents have low and moderate congnitive and executive levels to heifer development.

3-There is a significant correlation between the congnitive and executive levels to heifer development and and 5 independent variables i.e. age, educational level, exposure to multimedia, the degree of leadership and farm size.

4-There is a significant correlation between attitudes levels to small project of debtors and non debtors respondents and 4 independent variables i.e. age, educational level, exposure to multimedia, and cosmopolietness.

5-The previous five independent variables explained about $23.465 \%$ of variance in the cognitive and executive levels to heifer development .

6-Major problems facing debtors respondents in executed heifer development project were : there is no extension training programs and rations are not available.
\end{abstract}

